\title{
Effect of Covid-19 Pandemic on Unemployment Rate and Economic Growth: The Case of Ethiopia
}

\author{
Endashaw Sisay Sirah (MSc) Wondimhunegn Atilaw Woldetensay (MSC) \\ Economics Department, Mizan Tepi University, Mizan-Aman, Ethiopia
}

\begin{abstract}
As COVID-19 epidemic spreads all over, lowest, middle-income and developed countries are competing to respond to this gigantic and fast-moving challenge. Jobs are unable to find and economic recession of the COVID-19 crisis is gradually drumming low income countries more severely. This is a very large negative shock to the economy which is anticipated to knowingly lessen income of households and exaggerate the level of paucity. In developing nations unemployment is getting worse and the severity also higher than developed nation, mainly due to the unbalanced relationship between the rate of economic development and the rapid unemployment growth, in Ethiopia this unbalance also exaggerated with COVID-19 pandemic. High rate of economic growth indicate the need for additional labor market. On the other hand, recession indicates increase the unemployment rates due to lose in job. The study considered a secondary research approach by reviewing research findings that have been strained from scrutinizing the different sentiments, actualities and outcomes from researchers on the topic of impact of COVID-19 on unemployment rate and economic growth. Pointers from the findings are that COVID-19 is a global problem, which affects rich and poor countries. A popular classical theory in economics by John Batiste Say has for a second time futile as witnessed in 1930s due to Great Depression. The study look that supply creates its own demand again invalid due to COVID-19. In Ethiopia, if COVID-19 pandemic is sustained, under unemployment and long run unemployment have a great chance to occur in addition to Keynesian unemployment. The conclusion of the study is that there is direct relationship of COVID-19 pandemic and rise of unemployment rate and reduction of economic growth. Thus the government should give more attention than before to control the pandemic before face huge crisis in the country. Even huge government expenditure should be allocate to fight this pandemic by subsidize all sectors, to increase the hiring capacity of our economy.
\end{abstract}

Keywords: COVID-19, Economic Depression, Impact, Keynesian unemployment

DOI: $10.7176 /$ RHSS/10-13-02

Publication date:July $31^{\text {st }} 2020$

\section{Introduction}

The world large young population group is found in Africa; in this continent from 10 to 12 million peoples/youths join the labor force each year. Having this fact, the ongoing COVID-19 pandemic will likely make worse this trend. Significantly, at the beginning month of the pandemic the income of informal workers in the region reduced by $81 \%$. In Africa, $85.8 \%$ of employment, and $95 \%$ of youth employment, is informal. Mostly, informal work is often considered by low pay, erratic hours, uncertain employment status, and hazardous working conditions. Therefore, a country, especially African governments has been subject to affecting by COVID-19 pandemic and it needs great attention to overcome this problem as well as to safe there economy from recession (Munyati, 2020). "Africa is likely to be hit by at least $\$ 100$ billion in economic costs (or approximately $5 \%$ of gross domestic product (GDP)) this year as a result of the coronavirus crisis. As COVID19 reaches everywhere, low- and middle-income countries are racing to respond to this massive and fast-moving challenge. The economic impacts of the COVID-19 crisis are increasingly hitting low- and middle-income countries and the poor. This is a very large negative shock to the economy which is expected to significantly reduce income of households and aggravate the level poverty".

The problem of unemployment is a worldwide issue at the moment that every nation is striving to control it at its minimum level. However, in developing nations it is getting worse and the severity also higher than developed nation, mainly due to the unbalanced relationship between the rate of economic development and the rapid population growth. With this regard, the unbalance is aggravating the problem of unemployment. Even slip into some form of underemployment idle for productive work. Unemployment represents loss of potential output, the more the number of unemployed in a society, the higher will such a loss be. It is one of the key indicators of the economy and entails some cost to the individual unemployed person, to the family of the unemployed and the society at large. The high level of crime that characterizes many African countries and that is partly driven by high level of unemployment has further fuelled the problem of unemployment through its effect on these economies. The cost of crime prevention and, most importantly, the cost of doing business have gone up in many countries in sub-Saharan Africa. For improving the future of the unemployed, such state of affair also sends the wrong signal for potential external resources by stifling foreign direct investment (Astatike, 2003).

Unemployment is a problem for both developing and developed countries. However, the impact and 
intensity might differ. According to (Sumera, Shahzad, Muhammad, \& Muhammad, 2012) high unemployment implies resources are wasted, people's income is depressed. It has the most direct and strong influence on every individual. Denied employment for the majority of the population means a decline in the standard of living and causes serious, sometimes dangerous, psychological trauma. Also for the government, the unemployment rate is one of the most important indicators of the economic situation in the country. Additionally it is a socio-economic phenomenon, in which part of the labor force is not engaged in the production of goods and services. In actual economic life, unemployment appears as an excess of supply of labor over demand on it (Malika, Faisal, \& Nil , 2017).

Moreover, COVID-19 has exaggerated the level of poverty by retard economic growth and unemployed groups also become more severe than before. The COVID-19 has reduced the productive capacity of economy and even it reduced the demand for products which produced by producers, again it produce high unemployed rate. With other side, the main source for one economic growth is human resource, but COVID-19 has its own negative influence on population growth. In Africa and Ethiopia COVID-19 pandemic killed a number of human being. These dies also indicate as we lose many productive groups by this pandemic. Hence, the main objective of this study was to look the impact of COVID-19 on unemployment rate and economic growth.

\section{Methodology of the Study}

This study was mainly focused on the impact of COVID-19 on economic growth and unemployment, by considering Ethiopian economy as a case study, this country found in the horn of Africa. To conduct this study the author used literature reviews as a main input to look the impact of COVID-19 on Ethiopian economy. To analyze the result of the listed reports and empirical investigation the researcher used descriptive analysis. The review primarily considers WB reports, economic forums and empirical studies. In addition to those concerned investigations, the researcher dig out other helpful studies which is related the title of this review. Moreover, published materials are the source of the review which is downloaded from internet by using different journal documentations.

\section{Definition of COVID-19, Unemployment and Economic Growth}

COVID-19 is “disease caused by a new strain of coronavirus. 'CO' stands for corona, 'VI' for virus, and 'D' for disease. Previously this disease was referred to as '2019 novel coronavirus, or '2019-nCoV. It is a virus linked to the same family of viruses as Severe Acute Respiratory Syndrome (SARS) and some types of common cold" (CDC, 2019).

In our world, the problems of employment of the population in a market economy are becoming increasingly important. When the economies of many countries are on the verge of crises, unemployment can be one of the indicators of the complication of the socioeconomic situation of the government. It affects almost all segments of society, ranging from students to retired senior citizens. Unemployment rate is an important economic indicator which can help to identify the weaknesses or the power of certain countries economic economy (Nasridini \& Behrooz, 2015).

One can only be called as unemployed if he or she is: without work, that means he or she was not in paid employment or self-employment during a particular reference period; currently available for work, that means he or she was ready for a paid employment or self-employment during the reference period; Seeking work, that means he or she had taken specific steps in a specified recent period to seek paid employment (ILO, 1982). Unemployment rate is defined as the percentage of the labor force that is unemployed, which can be indicated as follows;

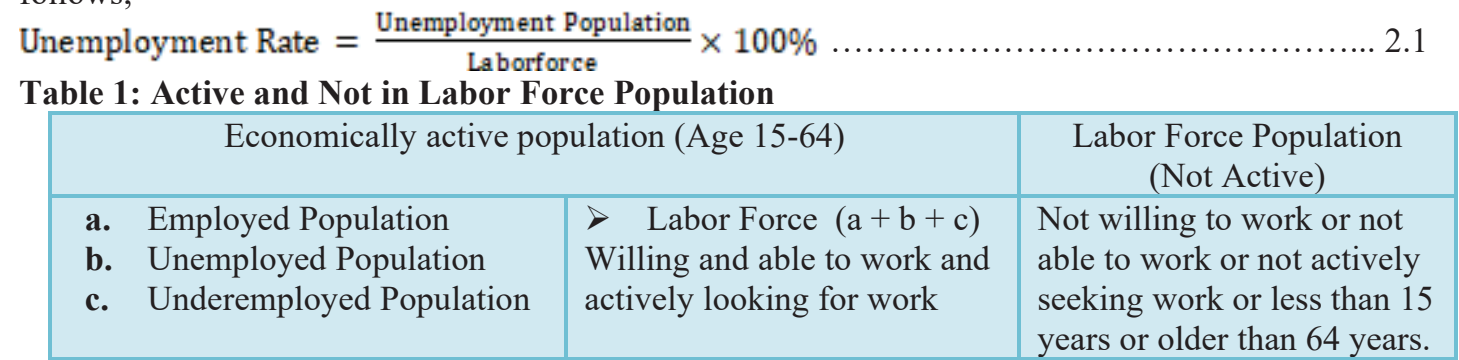

Real GDP is the market value of the goods and services produced by an economy over time. It is normally measured as the percent rate of increase in real gross domestic product (Dilek, 2016) and (Taylan, 2012). Gross domestic product measures the market value of all final goods and services produced within a country in a given period of time. As real GDP, measured at constant prices, is unaffected by price changes over time, changes in real GDP reflect changes in the amount of goods and services produced. Real GDP is thus a better measure of well-being in an economy. Since the mid-2000s onwards Ethiopia has enjoyed accelerated and sustained economic growth for more than a decade now, where growth rates exceeded global averages. It has become one 
of the fastest growing countries in the world. Therefore in addition to economic theory and other studies, this leads to eager the researcher to look COVID-19 pandemic effect on it.

\section{Taxonomy of Unemployment and Type of unemployment will Happen During COVID-19}

Types of unemployment categories might be loosely grouped into those related to the state of the economic activity at a given point in time, those that reflect the inherent workings of the economy. The following types of unemployment are identified to be defined: Frictional, Structural, Keynesian unemployment, seasonal, hidden unemployment, underemployment and long-term unemployment are the major ones. A brief description of each is given below.

\section{Frictional Unemployment}

It is the time period between jobs when a worker is search for, or transitioning from one job to another. Sometimes also called search unemployment and can be voluntary based on the circumstances of the unemployed individual. This category of unemployment is constantly at hand in an economy, so the level of involuntary unemployment is appropriately the unemployment rate minus the rate of frictional unemployment, which means that increases or decreases in unemployment are normally under-represented in the simple statistics. Frictional unemployment exists because both jobs and workers are not homogeneous, and a mismatch can result between the characteristics of supply and demand. Such a mismatch can be related to payment, skills, work-time, location, seasonal industries, attitude, taste, and a multitude of other factors. Graduating students or new entrants and re-entrants or former homemakers can also suffer a spell of frictional unemployment. According to economists be fond of Keynes along with Lerner, frictional unemployment is companionable with the concept of full employment; it is not a main problem because employable persons in quest of work will not, as a rule, remain unemployed for frictional reasons for more than a few weeks or months (Kayode, 2015).

The search takes as well long and mismatches are too common, the economy suffers, since some work will not get done. So, governments will seek ways to trim down unnecessary frictional unemployment throughout multiple means including provided that education, advice, training, and assistance. Aggregate demand or policy induced remedies may not remove this type of unemployment while the provision of better information for job seekers and employers can facilitate employment and reduce this kind of unemployment (Lenvine, 2013).

\section{Structural Unemployment}

It occur as a labor market is not capable to afford jobs for everyone who desires one because there is a mismatch between the skills of the unemployed workers and the skills needed for the available jobs. Even it is hard to separate empirically from frictional unemployment, except to say that it lasts longer. As frictional unemployment, simple demand-side stimulus will not work to easily abolish this type of unemployment. This sort of unemployment could also be encouraged to rise by continual cyclical unemployment: if an economy suffers from low aggregate demand, it means that many of the unemployed become discouraged, at the same time as their skills become rusty and obsolete. Problems with debt lead to homelessness and a fall into the vicious circle of poverty. This means, they may not fit the job vacancies that are created when the economy recovers. The implication is sustained high demand may also lower structural unemployment (Kayode, 2015).

More technological unemployment, due to the replacement of workers by machines, might be counted as structural unemployment. In other way, technological unemployment may refer to the way in which balanced increases in labor productivity mean that fewer workers are desirable to generate the same level of output every year. Technological changes that are not induced by factor endowment, say labor scarcity and high wage leading to labor saving technologies, rather determined by exogenous factors, may result in productivity growth at a faster rate than the growth of product demand (Bosworth, Dawkins , \& Stromback , 1996). This creates unemployment, as less labor is required to produce output that satisfies the stagnant demand. This kind of technological unemployment could be seen as demand deficient unemployment since it is the outcome of the adoption of labor saving technologies in the absence of local and international demand for the output. If labor saving adoptions of technology or innovations are taking place, under low domestic demand, they have to lead to higher exports in order to achieve higher employment in the domestic economy.

Seasonal unemployment may be seen as a kind of structural unemployment, since it is a type of unemployment, seasonal unemployment arises because of both supply side and demand side seasonality. Variations in product demand, such as seasons of festivities, lead to variation in the demand for labor associated with the production of that commodity. Production seasonality from the supply side, such as harvesting of agricultural produce, leads to the seasonal variation in labor demand. That is, it is either very expensive or physically difficult to bring the workers to where jobs are or to train the workers for the available jobs at a given point in time. Structural unemployment lasts longer and demand management does not easily eliminate it. To reduce this type of unemployment facilitation and implementation of training programs, subsidization of mobility of workers are required along with demand management instruments (Marjetka \& Ziga, 2015).

III. Keynesian Unemployment

Keynesian unemployment occurs if there is not enough aggregate demand in the economy to provide jobs for 
everyone who wants to work. Demand for most goods and services falls, less production is required and as a result fewer workers are needed, then wages are sticky and do not fall to meet up the equilibrium level, and mass unemployment results (Keynes, 1996). Due to COVID-19 pandemic, this type of unemployment has an opportunity to happen or occur in Ethiopia.

\section{Hidden Unemployment}

It is the unemployment of potential workers that is not reflected in official unemployment statistics, due to the way the statistics are collected. In many countries only those who have no work but they are actively looking for work are counted as unemployed. Persons who have given up looking for work are not formally counted among the unemployed, even though they are not employed. The statistic does not count the underemployed - those working fewer hours than they would prefer or in a job that doesn't make good use of their capabilities.

Moreover, those who are of working age but are currently in full-time education are usually not considered unemployed in government statistics. Traditional unemployed native society, who life on by means of hunting, gathering, herding, and farming in wilderness area, may or may not be counted in unemployment statistics. Official statistics sometimes underestimate unemployment rates because of hidden unemployment (David \& Vicente, 2012).

\section{Underemployment}

Underemployment represents the employment of workers having high-level skills in low paying jobs that do not require such abilities. For example, someone with a college degree may be doing secretarial jobs or serving as a taxi driver. This may be the result of a situation of unemployment where workers with financial responsibilities have to take almost any jobs available, even if they do not use their full capacities and skills.

Underemployment is also defined as under use of economic capacity, as under use of employed worker as in overstaffing. Disguised unemployment is also underemployment where people have little to do or produce while they are still retaining their employment status, due to lack of complementary resources or absence of demand for the output (Cymbranowicz, 2017).

\section{Long-Term Unemployment}

Long-term unemployment is an element of structural unemployment, which outcome in long-term unemployment obtainable in every societal group, industry, profession, and all levels of education. long- term unemployment is a result of a weak business hiring, which is the cause of an aggregate demand shortfall, the stigma attached to it that makes it harder for people seeking jobs to find employment in low and medium skill jobs because those employers care about long-term unemployment, while high skill jobs mainly focus on an applicant's past experiences instead of their long-term unemployment (David \& Vicente, 2012).

\section{Unemployment and Economic Growth Statistics in Ethiopia}

According to (Rafiq, Ahmad, Asmatullah, \& Khan, 2010), unemployment has been the most consistent problem in both developed and poor countries. In 2016 and 2017 for example, as indicated in the World Bank (2018), the general unemployment rate (as a \% of total labor force) stood at $24.30 \%$ in South Africa, 3.97\% in China, $4.40 \%$ in USA, 39.39\% in Bosnia and Herzegovina, $12.80 \%$ in Egypt, $4.30 \%$ in United Kingdom, 17.22\% in Spain, $11.20 \%$ in Algeria, $7.50 \%$ in Argentina and specifically in 2016 stood at $17.06 \%$ in Ethiopia. One of the strong facts of the labor market in Ethiopia is the rapid growth of labor supply.

Because of the young dominated demographic profile, the labor force is growing much more rapidly than the population as a whole. This is laborious because when workers are unemployed, there is an under-utilization of resources. So the total production of a country is less than its potential level of output because resources are not fully utilized in these countries (Muhammad, TahirMahmood, \& Bhalli, 2013). According to Africa union report due to COVID-19 around 20 million of jobs, both in the informal and formal sectors, are threatened with destruction.

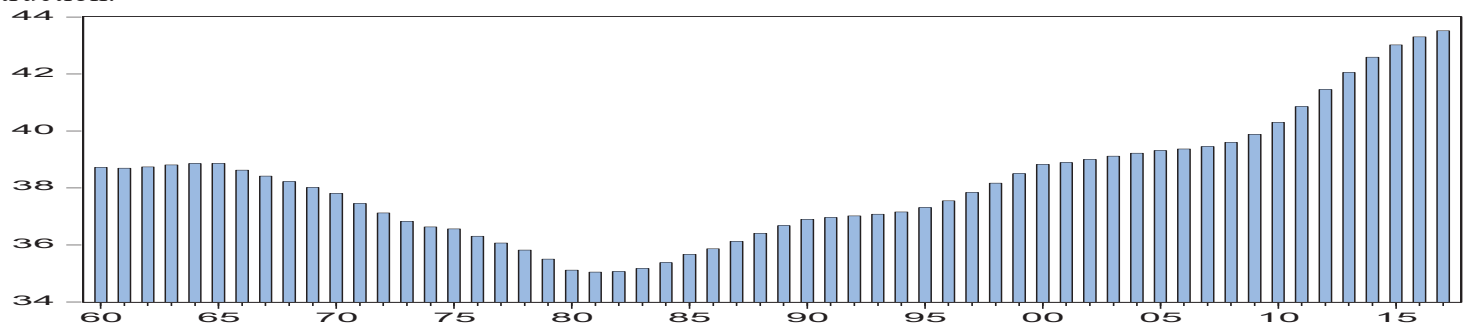

Figure: Ethiopia Population Ages 15-24, \% of Total Population

Source: World Development Indicators (2020) 


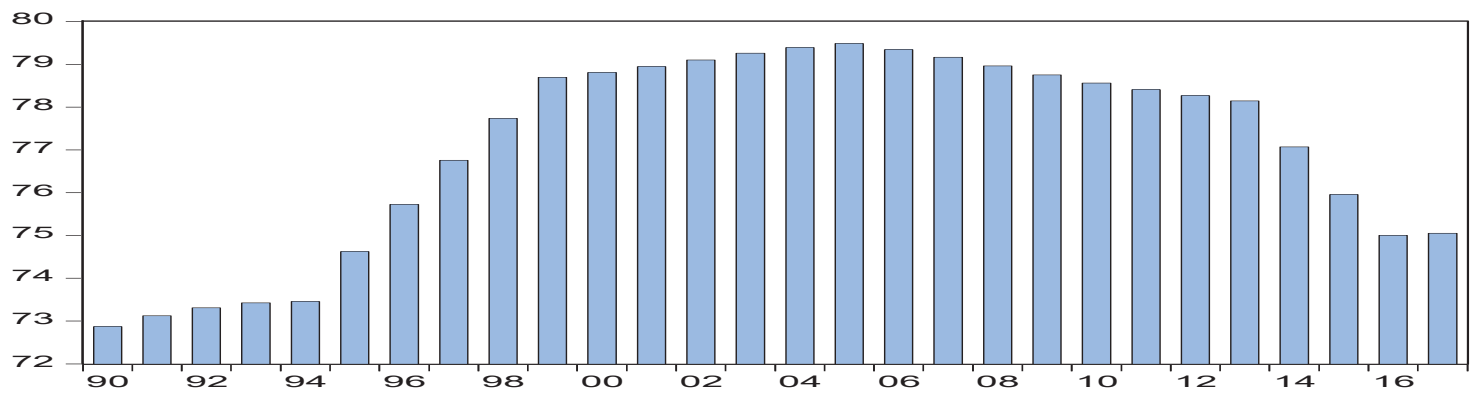

Figure: Ethiopia Participation Rate for Ages 15-24, Total (\%)

Source: World Development Indicators (2020)

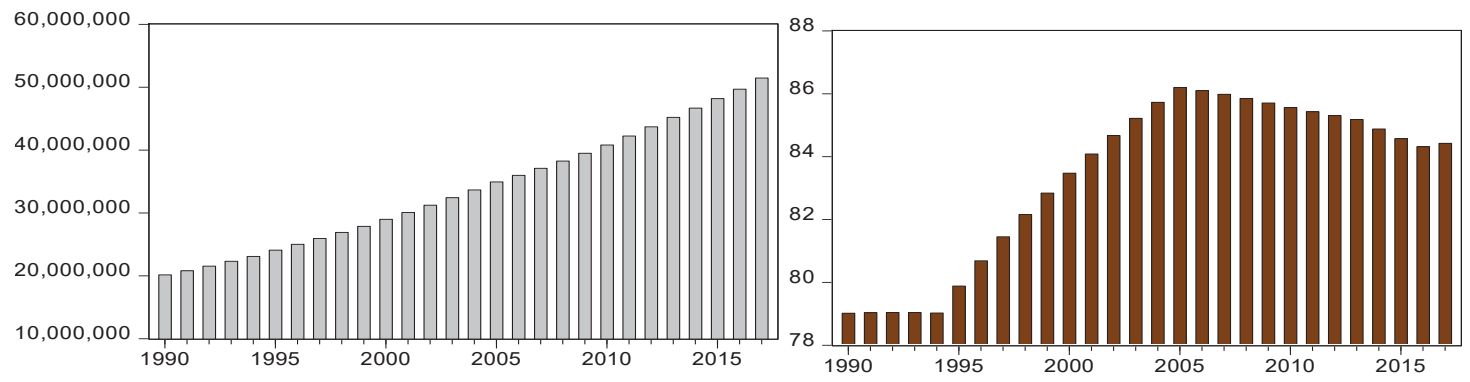

Figure: Ethiopia Labor Force Participation Rate (Labor Force Total) and Total (\%)

World Development Indicators (2020)

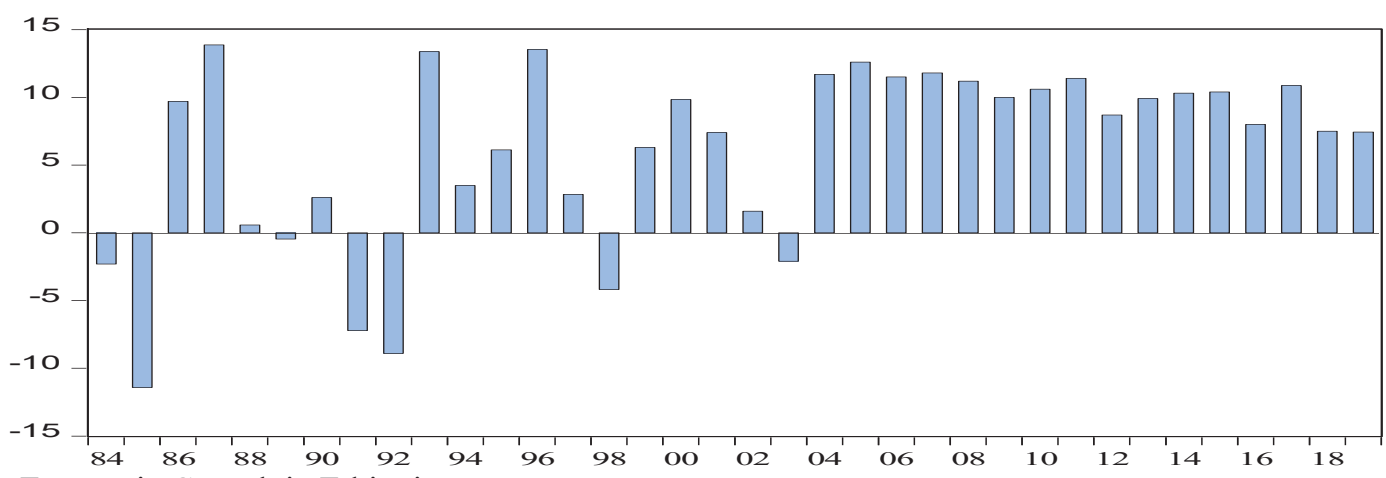

Figure: Economic Growth in Ethiopia

World Development Indicators (2020)

Ethiopia is the second most populous nation in Sub-Saharan Africa, next to Nigeria. Not only is the size of her population but it also growing relatively at a rapid rate. One interesting feature of the growth rate of the Ethiopia's population is its strong correlation with the growth rate of the country's working age population.

\section{Some Actions which Taken in Ethiopia to Prevent COVID-19 Pandemic}

Around the world "governments are closed educational institutions from the pre-primary to the tertiary level to stop the spread of COVID-19 pandemic and to reduce health risks for students, teachers and non-academic staff. COVID-19 has turned the world upside down. The problem is more severe in developing countries than in advanced ones for various reasons". Approximately 1.725 billion learners are currently affected due to school closures in response to the pandemic. Cross country, schools in Ethiopia closed due to COVID-19 on 16 March 2020, "following the declaration of the virus as a pandemic by the World Health Organization on 12 March 2020". On 16 March 2020 the government closed schools across the country immediately after the announcement of the first five COVID-19 cases. The five-month state of emergency which the country declared bans gatherings which also affect schools. And, currently, universities are being used as quarantine centers, sanitizer producer and they are busy for providing other social service which is related from preventing COVID19 (Hailu , 2020) and (Kandri, 2020).

Through time Ethiopia government exercised different methods to sustain and there is little hope that education would continue in a country where digital learning stands very much poor. But through time, ministry of education ordered to deliver courses by using Radio, TV, Telegram, You tube, Zoom and other plat form also created by cooperated from ethio-telecom to provide teaching and guide books for students, but all the above listed mechanisms are questionable to reach economically poor and disable students and even education quality 
may goes to at risk and its achievement to produce productive and knowledgeable graduates. Some of the stated technologies are not used appropriately by students and teachers, because we are poor in knowledge regarding to utilize technology to deliver or teach courses without face to face or online.

Government, health experts, artists, comedians and intellectuals are busy by giving awareness regarding to the expansion and avert way of COVID-19 be contingent up on World Health Organization (WHO) order for their people by using different method. The main acceptable prevention mechanize at now which delivered for each peoples are, wash our hands repeatedly, avoid touching eyes, nose and mouth, put space between our self and others or practice physical distancing and cough or sneeze into your bent elbow or a tissue. To reduce this pandemic, the government is applied lock down for two weeks, which was no transport from Addis Ababa to regional towns and with parallel regional governments also stop any transport from zone to district but it was not sustain. Using mask also became as an obligation. To do not throw from airline market competition, Ethiopian Airlines' also try to shift from human being vacationer to cargo services but it is not as such good to cover revenue which comes from passengers.

Other measurement also which employed to prevent the expansion of COVID-19, Ethiopian government make free some prisoners. Blocking of night club, Edirs and Equibs and the like and partially religious places are blocked for some period. Churches, Mosques prayer program was conducted for one month by using FBC, EBC, WTV and ETV media to eradicate the corona virus from the country. From the capital city a number of street peoples are sent to their region and collected on a specific place by providing appropriate food and training. Ethiopian government got masks and other foreign aid from different countries to increase the control capacity of corona virus. The government and Ethiopian people highly applying a great job to mobilize resources and to reach vulnerable groups. Government and private workers are partially prevented to going their office repeatedly instead they are requested to practicing their responsibility from home and try to get their customer through online but its productivity is questionable. Sharing of meal idea was also created by our PM to safeguard the vulnerable group from famine. This is stated as follows by (Geda, 2020) "the PM Abyi's idea of sharing our

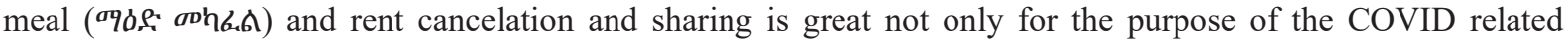
challenges" and for other social life interdependence.

Strong border controls also practically strengthen to control a new entrant from neighbor countries, if new entry come from abroad by any means they had been goes to quarantine. A number of actions are taken on transport sector, sharing and supporting of meal for disable and economically poor groups also continued with many charity groups.

\section{Impact of COVID-19 Pandemic for the Rise of Unemployment and Reduction of Economic Growth}

Regarding to export, especially Ethiopia is a net exporter of coffee, but when we consider this and by this year the price of it reduced more than $10 \%$, Flower, Chat and Leather product export also decline, due to this revenue will reduced, the response of this has its own negative contribution on economic growth and reduction of employment. Due to this pandemic the tourism and airline sector highly at threat, i.e. around $\$ 35$ billon of international receipts is at risk. Moreover, hotel employment generation reduced to $50 \%$ in Ethiopia and Ethiopia airline lost \$190 million for the first two months of 2020, this loss of revenue has negative impact on Ethiopian economy. With the COVID-19 pandemic social tension increased like some goods and services price increased over expected, job opportunity highly reduced and private workers are at risk. This pandemic has increased the amount of debt, reduced countries revenue by blocking money income generator sectors from being productive. Ethiopian economy mainly depends on primary product export and import processed products, even more of the daily consumption products are comes from abroad (Munyati, 2020).

So if the COVID-19 pandemic affect worldwide economy, import side also negatively affected by this pandemic especially by increasing price, it may make difficult the import of goods and services delivery system. If there is no enough export the country may face shortage of foreign hard currency. A large number of Ethiopian people lead their life in abroad, than of Ethiopia COVID-19 pandemic highly triumph other developed countries this may lead for the reduction of remittance, by this rational reasons the country may not have a capacity to import all goods and services which used for consumption of the domestic people and even it became difficult to import other capital goods and producer not become productive and efficient then this lead for the reduction of economic growth and high unemployment. According to Okuns law when economic growth decreased unemployment will raise, then this become a main source for economic and social effects, a multidimensional phenomenon will happen.

When impact of COVID-19 pandemic increase, this principally increase the level of unemployment and reduce economic growth, because COVID-19 pandemic throw or deprived the necessary and productive human capitals by using different mechanism like by reducing the employing capacity of employers and plus it leads to fire their existing workers. According to (Sisay, 2020), high unemployment and low economic growth become as a seed to produce poor country, terrorism, racism, financial hardship, poverty, homelessness, frustration, family tension, social isolation, loss of self-confidence, loss of hope and self-esteem, with hope but for without 
living standard change it invites peoples for migration. According to (Geda, 2020) the most vulnerable groups are employees in the private sector, COVID-19 pandemic become as hinder to run their business with full capability. Those employers have obliged by Ethiopian government to do not fire their workers but if the government does not finance and the pandemic sustain for long period, they have not become volunteer to hold more job seeker and pay for their workers. The second vulnerable groups with COVID-19 pandemic are selfemployed. Other vulnerable groups are small \& micro enterprise.

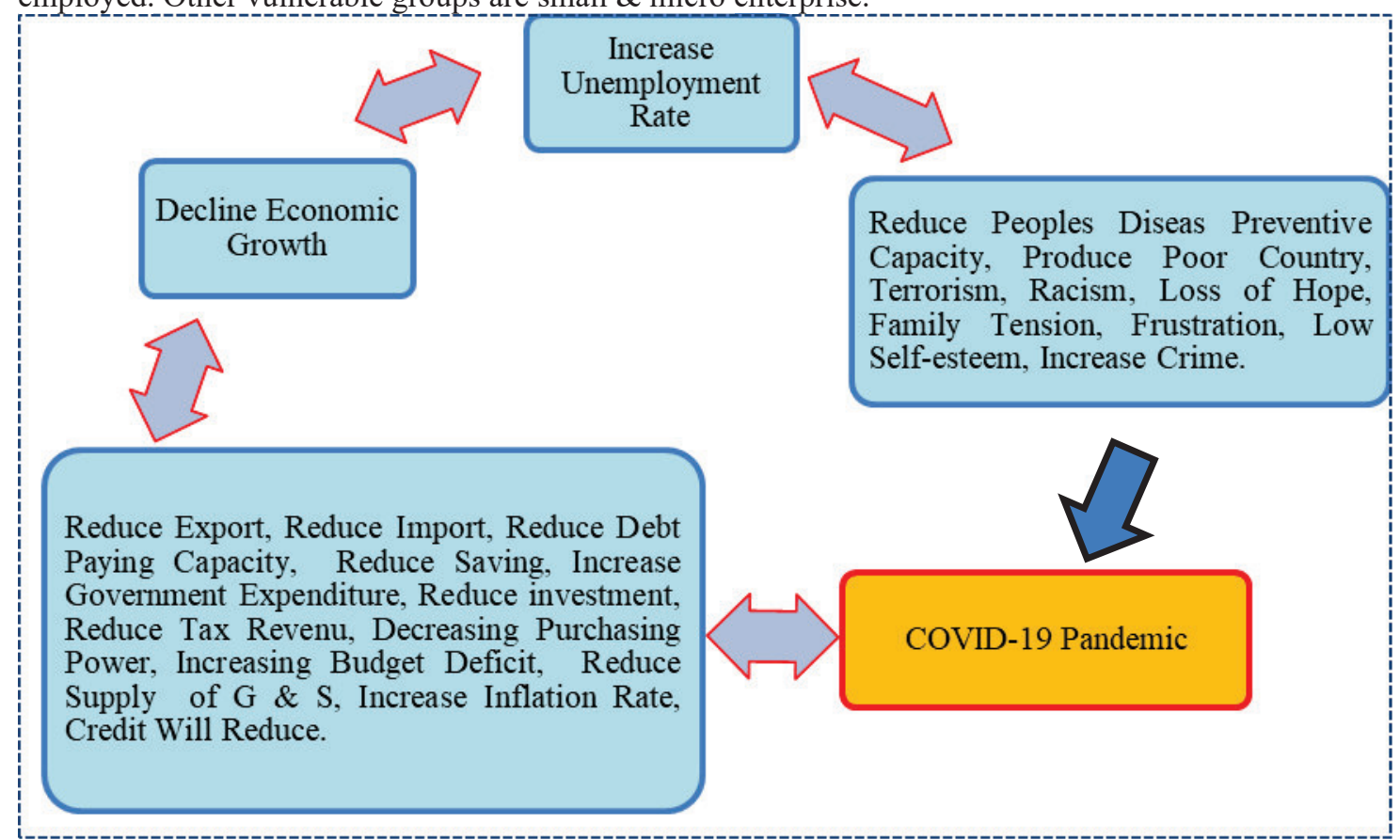

Figure 1: The link of COVID-19 pandemic, Economic Growth and Unemployment Rate

Source: Author (2020)

Ethiopia and other developing and developed countries also announced different reprieve inventiveness to counterbalance Covid-19 sound effects. More or less all this effort of governments is to increase export, increase import, and reduce debt paying capacity, increase saving, reduce government expenditure, increase investment, Increase tax revenue, increasing purchasing power, reduce budget deficit, increase supply of Goods \& services, reduce inflation rate, and credit will increase.

According to (Geda, 2020) "The impact of the COVID-19 pandemic is estimated to reduce GDP by 11.1 percent in the fiscal year 2020/21 (as well as the last quarter of the current fiscal year); This shock is found to be the highest in the industrial sector which is expected to shrink by 17 percent. This will be followed by the services sector which is expected to shrink by 15.6 percent. The agricultural sector is expected to be the least affected as it is expected to contract by only 1.6 percent".

\section{The Challenges of Unemployment}

Unemployment is one of the major challenges facing today's world. Coupled with population growth and increased poverty, it has a significant impact on growth and development at large. It causes a waste of economic resources such as the productive labor force and affects the long run growth potential of an economy. Unemployment gives rise to private and social problems in the society such as increased crimes, suicides, poverty, alcoholism and prostitution (Rafiq, Ahmad, Asmatullah, \& Khan, 2010). When workers are unemployed, their families lose wages, and the nation as a whole loses their contribution to the economy in terms of the goods or services that could have been produced. Unemployed workers also lose their purchasing power, which can lead to unemployment for other workers, creating a cascading effect that ripples through the economy.

Unemployment even affects those who are still employed. When workers are let go, it increases the amount of work those who are still employed have to cover. And because unemployment usually increases when companies are trying to cut costs, those expected to pick up the slack are not receiving any additional compensation for extra hours worked. Unemployment can also have a negative mental effect on those who are still working. They may become more concerned about losing their own jobs or be hesitant to look for something better because they "are lucky" to be employed at all. They may even feel guilty about having a job when their co-workers are out of work.

To better understand the nature of unemployment, policymakers need information on many aspects of it, 
including the number of unemployed people, the period of time for which they have been unemployed, their skill levels, the trend in unemployment, and regional disparities in unemployment. Once these statistics have been obtained and interpreted, policymakers can use them to make better-informed decisions about steering the economy and countering unemployment.

According to (Rafiq, Ahmad, Asmatullah, \& Khan, 2010) and (Joel \& Johannes, 2010) unemployment has a great impact on growth and development at large and it causes a waste of economic resources the productive labor force and affects the long run growth potential of an economy. If peoples cannot find jobs in their home country, they may be inviting to relocate to another country for getting jobs. This can be harm for the future of a nation, particularly if other nations are attracting its brain drain. Therefore, if this problem uninterrupted in any economy, it could be a major factor in deteriorating the economic growth. Moreover, persistent unemployment not only affects the position of a nation in comparison to other nations, but it also leads to suffering home country problems. Another explanation may be that unemployment might be more serious through creating political instability. If people are left with no alternative, they are more liable to join an uprising as an alternative way of generating earnings (Sisay, 2020).

\section{Conclusion and Some Possible Solutions}

Keynesian economists notice the lack of demand for jobs as potentially resolvable by government interference. For this one suggested interventions involves deficit spending to boost employment and demand. Interference involves an expansionary monetary policy that increases the supply of money which should trim down interest rates which should lead to an increase in nongovernmental expenses. The Keynesian analysis focuses on the recovery policy through demand; the common belief of most economists is that unemployment will be decreased automatically since the economic growth is high. Another liberal view focuses on the supply, which is by supporting the cost effectiveness and profitability of projects. However, it is noticeable that there is significant correlation between growth and changing rate of unemployment.

High rate of economic growth designate the need for additional labor market. On the other hand, recession indicates increase the unemployment rates due to lose in job. "Supply creates it's a own demand " a popular classical theory in economics by John Batiste Say has again failed as witnessed in 1930s due to "Great Depression".

Due to Covid-19 the demand for labor is shirked to its lowest level and it is expected that labor price decrease, most producers are not much volunteer to employ job seekers because of low demand for products and unemployment rate will high. For that reason; today over again, as in 1930 due to great depression, now due to Covid-19, Say's law, supply creates its own demand, failed and it is again triumph for Keynesian Economist who are the great prophets of Demand creates its own supply.

Policy makers, governments and economists to devise such strategies are both on fiscal and monetary fronts. On fiscal front government should announced relief packages to the industries, SMEs and common masses to maintain aggregate demand. Moreover; on monetary front the national banks of country should go for Expansionary monetary policy to encourage investors to invest in different sector with low cost of debt servicing. Moreover the people as a whole and charity groups specifically should increase their cooperation to safe unemployed, disable and orphan children's, even the people should prevent any illegal group's movement. To increase the hiring capacity of our economy, government expenditure should be allocating properly to fight this pandemic.

\section{References}

Astatike , H. G. (2003). The incidence of youth unemployment in urban Ethiopia. Department of Economics, Lancaster University.

Bosworth , D., Dawkins , P., \& Stromback , T. (1996). The Economics of the Labor Market. England: Addison Wesley Longman.

Cymbranowicz, K. (2017). The Phenomenon of Underemployment and the concept of flexicurity in the Labor market in Poland. Uniwersytet ekonomiczny wkrakowie.

David , C., \& Vicente, R. (2012). Unemployment and long-run economic growth: the role of income inequality and urbanization. Journal of regional Research.

Dilek, S. (2016). Determinants of Unemployment: Empirical Analysis for China. The Journal Of Academic Social Science, 50-58.

Geda, A. (2020). The Macroeconomic and Social Effect of COVID-19 in Ethiopia and Suggested Direction for Policy Response. Department of Economics, AAU. Retrieved From: https://www.researchgate.net/publication/340938630_The_Macroeconomic_and_Social_Impact_of_COVI D-

19 in_Ethiopia_and_Suggested_Directions_for_Policy_Response/link/5ee173bda6fdcc73be700bd5/downlo $\mathrm{ad}$ 
Hailu , B. H. (2020). Educa Tion Response To Covid-19: How Can Basic Educa Tion Be Implemented In Ethiopia? Retrieved from: https://www.ukfiet.org/2020/education-response-to-covid-19-how-can-basiceducation-be-implemented-in-ethiopia/

ILO. (1982). Resolution Concerning Statistics of the Economically Active Population Employment. Geneva.

Joel, H. E., \& Johannes, M. A. (2010). Determinants of Unemployment in Namibia. International Journal of Business and Management, 92-104.

Kandri, S.-E. (2020). How COVID-19 is driving a long-over due $r$ evolution in education. Retrieved from: https://eonreality.com/how-covid-19-is-driving-a-long-overdue-revolution-in-education/.

Kayode, B. A. (2015). The Relationship between Inflation and Unemployment in Nigeria, Submitted to the. Eastern Mediterranean University.

Keynes, J. M. (1996). The General Theory of Employment, Interest and Money. London: MacMillan.

Lenvine , L. (2013). The increase in unemployment since 2007: Is it cyclical or structural? USA: Congressional Research Service 7-5700, CRS Report for Congress R41785.

Malika, S., Faisal, F., \& Nil , R. G. (2017). Influence of energy use, foreign direct investment and population growth on unemployment for Russian Federation. 9th International Conference on Theory and Application of Soft Computing, Computing with Words and Perception (pp. 22-23). Budapest, Hungary: ICSCCW.

Marjetka, T., \& Ziga, C. (2015). Impact of Population Ageing on Unemployment and Entrepreneurial Activity:the Case of Slovenia. Organizacija.

Muhammad, S. M., TahirMahmood, A. S., \& Bhalli. (2013). Determinants of unemployment Empirical Evidences from Pakistan. Pakistan Economic and Social Review.

Munyati, C. (2020). COVID-19 is 1 ikely to incr ease youth unemployment in Africa, this is how business can mi tigate the damage. Knowledge Lead, Africa, World Economic Forum.

Nasridini, A., \& Behrooz, G. (2015). Factors Influencing High Unemployment in Tajikistan. International Journal of Social Science Studies.

Rafiq, M., Ahmad , I., Asmatullah, \& Khan. (2010). Determinants of Unemployment: A Case Study of Pakistan Economy. Abasyn Journal of Social Sciences.

Sisay, E. (2020). Macroeconomic Determinants of Unemployment in Ethiopia. Global Scientific Journal, 8(02), 4718-4729.

Sumera, A., Shahzad, K., Muhammad, K. N., \& Muhammad, T. (2012). Unemployment Reasons and Its Impact on Pakistan Economy. City University Research Journal.

Taylan, T. D. (2012). Macroeconomic Variables and Unemployment: The Case of Turkey. International Journal of Economics and Financial, 71-78

WDI.(2020). World Development Indicators. Reterieved From: https://datacatalog.worldbank.org/dataset/worlddevelopment-indicators. 